\title{
A DISCUSSION ON LEGAL PHILOSOPHY IN RUSSIA WITH PROFESSOR MIKHAIL ANTONOV ${ }^{1}$
}

Interview conducted by Natalina Stamile ${ }^{2}$

This interview was conducted during the 5th International Legal Philosophy Symposium - Research network Brazil, Russia, Argentina and Italy - on the $25^{\text {th }}$ and $26^{\text {th }}$ of May, 2017, hosted by the Postgraduate Program in Law at the Federal University of Paraná, Brazil. The main topic of the event was "Conceptions of the Legal System"3.

Q: First of all, thank you so much, Professor Antonov, for accepting this invitation. Could you start, please, by giving a brief introduction?

A: I am a professor associated with the Department of Theory and History of Law and State at the National Research University Higher School of Economics. My university, St. Petersburg State University, has four campuses: in Moscow, Saint Petersburg, Nizhny Novgorod and Perm. I am working at the Saint Petersburg campus, where I teach legal theory, comparative law and Russian legal philosophy. We do not have legal philosophy as a teaching discipline. But the matters that we consider within legal theory are almost the same, although less abstract and more closely connected to national law.

Q: Why did you choose to study legal philosophy? Who are the authors or legal philosophers who most influenced you and your work?

A: My choice to study legal philosophy can be explained by a set of different practical reasons. On one hand, it is about my inclination towards decomposing large intellectual frameworks and narratives into parts, examining the values and methods on which these frameworks are based. On the other hand, I have degrees in law, economics and sociology, which has prompted me to analyze concepts and facts from different standpoints. This led me to philosophy; first, to social and political philosophy, and then to legal philosophy.

Q: Can you talk about what it is like to be a legal philosopher today, especially in Russia? Has it changed at all, over the years? If so, how?

A: Legal philosophers have a bad reputation among lawyers due to their addiction to abstract frameworks and grand narratives, which are often detached from the real world. In many cases, this reputation is well merited. We do not have "legal philosophy" as a teaching or research discipline at law faculties - this subject is sometimes taught at philosophy schools, and Ph.D. theses focus on legal

\footnotetext{
${ }^{1}$ University webpage: <https://goo.gl/EtvkYw>. Advocate profile: <https://goo.gl/D5pgZq>.

${ }^{2}$ Ph.D. in Legal Theory and European Legal Order, Magna Graecia University, Catanzaro, Italy; post-doctorate in the Postgraduate Program in Law at the Federal University of Paraná, Brazil; visiting professor of Philosophy and Legal Informatics at the University of Bergamo, Italy.

3 The author would like to thank the Academic Publishing Advisory Center (Centro de Assessoria de Publicação Acadêmica, CAPA - <www.capa.ufpr.br>) of the Federal University of Paraná (UFPR) for assistance with English language editing. The author gives special thanks to Daniel Persia, Fulbright English Teaching Assistant at UFPR, for guidance during the editing process at CAPA.
} 
philosophy only at philosophy schools. That is why, in Russia, we have few people practicing legal philosophy; most of them are philosophers who have no legal background but still speculate about the law. This does not improve the bad reputation of legal philosophers at all. It was different in Imperial Russia, before the 1917 Revolution, when we had keen and distinguished legal philosophers working as law professors. But the situation has changed.

\section{Q: Within the field of legal philosophy, what more can you say about specific legal theory in Russia? Is there a specific legal theory that has influenced you most? Why?}

A: For known historical reasons, our philosophy was based on Marxism-Leninism, as well as the law. Thinking about basic conceptions and methods of legal cognition, understanding the nature of the law - in our legal education, many things still rest on the previous intellectual frameworks of Marxism. This reality differs greatly from that of philosophers more closely aligned to Habermas, Luhmann, Dworkin and other Western thinkers. In the beginning of my research, I was fascinated by legal sociology (Ehrlich, Weber, Gurvitch, Pound and others), but after a while I understood that these grand ideas and frameworks have almost nothing to do with my work as a practicing lawyer. I was, and still am, engaged in legal practice, both as a consultant and as an attorney. In fact, I am a barrister in commercial law and a partner at a law firm. For this reason, I turned my attention to legal positivism. Perhaps meeting Eugenio Bulygin in 2008 was one of the decisive points in my theoretical change. I started translating his and Alchourrón's Normative Systems and merged into the methodological problems of legal positivism. I was enchanted by the strictness of Kelsen's theory and the elegance of Hart's constructions. Still, to me, these three names stand out as the best legal philosophers.

Q: As you mentioned, you also translated Normative Systems (1974), by Carlos Alchourrón and Eugenio Bulygin, with Elena Lisanyuk. What is the influence of Alchourrón and Bulygin's theory in Russia? What are some of the other most important legal philosophies studied in Russia?

A: It took me more than three years to translate Normative Systems into Russian, which was really a very hard enterprise. I was in desperate need of advice from logicians, so I met with Professor Elena Lisanuyk, who is now a very good friend of mine. We published the translation in 2012. It exerted certain influence on logicians and on some legal scholars, but the effect was actually quite limited. Reading Normative Systems requires attentiveness, patience and knowledge of logic, and these properties sometimes are missing in the minds of legal scholars. My estimation is that the most known philosophers are those from the remote past - from Plato to Hegel, and also Russian philosophers of the late $19^{\text {th }}$ century and the first half of the $20^{\text {th }}$ century, such as Soloviev, Chicherin, Berdyaev and others. I think that most citations in scientific treatises are made to them. Western legal philosophers from the $20^{\text {th }}$ century are also known, but, as to their "popularity" among legal scholars, they are lagging behind. The problem is, as I see it, that their ideas are not taught at many law schools, so their names and conceptions are not familiar to most Russian lawyers. 
Q: What do you think about the legal theory of Alexy, Dworkin, and Habermas in relation to the Russian legal context?

A: These thinkers are, to a certain extent, known in Russia. Alexy's Begriff und Geltung des Rechts was published in Russian in 2011 and gained success among non-positivisticly minded legal scholars. Some of Dworkin's books are also translated and cited (the most influential being Taking Rights Seriously, published in Russian in 2005). But Alexy and Dworkin's ideas are, in fact, very far from our realities. Most lawyers and judges are trained to accept the law only as a set of rules and ordinances that absolutely have to be enforced. The judicial freedom to balance and weigh rights, or to decide cases based on the best interpretation of the law, sounds rather unrealistic in the Russian context. Habermas is even more difficult. Only a few legal scholars are studying his theory. My Doktorvater (doctoral advisor), Professor Polyakov, is deeply inspired by Habermas; he writes and teaches based on Habermas' philosophy. Me, personally, I cannot make much sense of Habermas' ideas as applied to the law.

Q: Today, Russia seems to be rediscovering its ancient role in many different fields. What is the current situation in regard to human rights, fundamental rights, and, in particular, religious freedom in Russia? Do you think the door has been opened for further discussion, research and advancement in these areas? Can you indicate one important decision made recently by the Russian Constitutional Court?

A: Russian exceptionalism has several factual and intellectual sources. For me, it is interesting to see how the criticism of human rights is justified by politicians and scholars in reference to Russian history. Russia used to be an authoritarian country with communitarian traditions and with little respect for human individuality. The Orthodox Church was always skeptical about individual freedoms, prioritizing the common interests. This is also reflected in Russian philosophy which, historically, for the most part, has been based on traditionalism and communitarianism. Nothing has changed during the Soviet rule as, despite different reference points, philosophy has remained entrenched in the same values and principles. Things slowly began to change in the years of Perestroika; the people were rapidly disappointed in liberal values which were intuitively associated with the economic and political downfall, extreme poverty and exorbitant corruption. This critical attitude is still prevalent and feeds the conservative rhetoric and policies of the Russian authorities. The Constitutional Court follows this trend; its interpretations are becoming more and more conservative, and sometimes these interpretations contradict the literal meaning of the Constitution. The most discussed is Ruling No. 21-P made in 2015 on the issue of prevalence of international law. The Russian Constitution (para. 4 of Art. 15) plainly makes international law an integral part of Russian law and gives international law priority in the case of collision. But the Constitutional Court ruled that the Constitution shall stand over international law and, therefore, laws adopted in accordance with the Constitution may not be set aside because of their purported contradiction to the international law (including the interpretations made by the ECtHR and other European and international courts and agencies).

Q: Do you have any recommendations for students or researchers who are at the beginning of their studies in legal philosophy?

A: Break free from prejudices and try to think critically about the accepted truths. 
Q: What fundamental texts would you recommend? Do you think Literature can play a role in law? How about film? What film might you suggest for a student new to the field?

A: Kelsen's Reine Rechtstheorie is really indispensable for continental lawyers, and I require my students to read it. Any law student who has not read this book will never fully grasp the subject matter of his or her study - what law is and how it works (at least in continental law). I am not a partisan of "Law and Literature" or "Law and Movies" and believe that they are rather detrimental to good legal education. Novels are written - just as movies are filmed - to affect human feelings and emotions. They are not made to learn and understand the law. You may, surely, decorate your narratives with some examples from novels or movies, but to devise from this a methodology of legal cognition is an exaggeration. So, my suggestion is: read literature and watch films for aesthetic pleasure or just to pass your free time, but not to learn anything about the law.

Thank you very much for talking with me. I look forward to meeting with you again soon! 